Article

\title{
Towards Non-Ageist Housing and Caring in Old Age
}

\author{
Shelly Cohen ${ }^{1,2, *}$ and Yael Allweil ${ }^{2}$ \\ ${ }^{1}$ The David Azrieli School of Architecture, Tel Aviv University, 6997801 Tel Aviv, Israel; E-Mail: local.shelly.c@gmail.com \\ ${ }^{2}$ Faculty of Architecture and Town Planning, Technion IIT, 3200003 Haifa, Israel; E-Mail: aryael@technion.ac.il \\ * Corresponding author
}

Submitted: 30 June 2020 | Accepted: 18 August 2020 | Published: 12 November 2020

\begin{abstract}
This article investigates aging-in-place among seniors who live with caretakers, particularly domestic workers who immigrate to Israel from poorer countries. In recent decades, new apartment designs are intended for families with children. Drawing on Dolores Hayden's (1980) 'Non-Sexist City', we expound on Non-Ageist architecture for the aging population and migrant caregivers. We examine how this kind of residence can include additional and vulnerable groups in the population, such as seniors and their caregivers. Our study explores the design of Tel Aviv Metropolis apartments. We argue that typical apartment design affects the ethics of everyday living. Following Michel de Certeau (2011), our research observes everyday behaviors and creative tactics through which seniors and caregivers re-appropriate shared living space. Most seniors house caretakers in a room within the bedroom area of the apartment, for instance, while others use a separate room by the entrance. These practices point to hierarchy and equality as spatial aspects of typical apartments' layout and their effect on their usage by seniors and caregivers. Our research explores the potential of a planning proposal-dividing the seniors' apartment into a primary apartment and a secondary unit-suggested by the inter-ministerial government team in the National Housing Headquarters and by the Israeli Affordable Housing Center, an academic-social organization. We argue this division could enable better housing solutions for shared residency. Thus, the article combines qualitative research of residence in old age with analysis of the role of social values such as equality, autonomy, inclusion, affordability and communal values in old-age housing and care.
\end{abstract}

\section{Keywords}

aging; apartment design; architectural design; care; caretaking; equality; everyday ethics; hierarchy; Israel; work immigration

\section{Issue}

This article is part of the issue "Built Environment, Ethics and Everyday Life" edited by Mattias Kärrholm (Lund University, Sweden) and Sandra Kopljar (Lund University, Sweden).

(C) 2020 by the authors; licensee Cogitatio (Lisbon, Portugal). This article is licensed under a Creative Commons Attribution 4.0 International License (CC BY).

\section{Introduction}

Since the late 1980s, the intersection of global social processes-such as an aging population, work immigration, and a shift of welfare policy towards community care-have culminated in a new form of residence in Israeli society: Seniors share their residential space with their caregivers. In Israel, life expectancy at birth is at a record high ( 82.29 for both sexes in 2016; World Health Organization, 2018). While regarded as a 'young' country compared to Europe, Israel's population is aging rapidly.
In 2018, people aged 65 and above were $11.8 \%$ of the total population. The population over 85 is expected to grow at a faster pace than populations over 65 (Israel Central Bureau of Statistics [Israel CBS], 2019a). Israel's welfare policy encourages aging in place-the average age of those entitled to the caregiver benefit is about 83; they receive the allowance for approximately five years (Assiskovich, 2017). This policy and old people's desire to remain in their home leads them to employ live-in caregivers. Following the pioneering research of American urban landscape and architecture scholar Dolores Hayden 
on the housing needs of unique groups in society, we identify the aging population and immigrant caregivers as inter-related groups whose living conditions require examination (Hayden, 1980). Our research focuses on the ways in which housing environments take part in producing the conditions of care in everyday life.

Both scholars and government regard aging as an acute problem for Israeli society. While extensive research and policy is conducted in the fields of gerontology, health systems, and social work, the spatial aspects of housing for old age are yet to be examined. This article focuses on the architectural scale, design of apartments, and their adjustments for later phases of life; and asks: How does apartment design shape an equitable relationship between seniors and caregivers? Dwelling apartments where care is practiced are regular apartments designed for large families. By focusing on one key dwelling solution common in Israel, the shared dwelling of seniors and caregivers in the seniors' own urban apartments, we therefore ask: What can be learned about the suitability of typical residential apartments for old people with caregivers? How can this information be translated into the $a b$ initio design of residential apartments, so that they are suitable for care of the elderly?

This housing type, where retired seniors and their 24/7 caregivers spend their entire days, thus transforms into more than dwellings per se. As senior and caregiver share the dwelling apartment, it becomes a workspace, a clinic, and a temporary home for the caregiver. Shared habitation of seniors and their migrant caregivers therefore consists of a new type of housing on the Israeli market, where planning policies of aging-in-place intersect with the privatization of public services in the early years of the twenty-first century (Katan, 2002). These privatization policies aim to replace the creation of nursing homes isolating the aging from the rest of society, by directing that care for seniors be mostly provided in their homes, but not by their family members. Round-the-clock careusually done by immigrants-is partly subsidized by the National Insurance Institute of Israel (Doron, Bar, Adut, \& Gan-Mor, 2016; lecovich, 2011). Currently, about 69,000 migrants, documented and undocumented, work as caregivers (Abrahams, 2020).

Labor migrants became an important part of the workforce following the first intifada in 1987. The possibility of Palestinians working in Israel was restricted but, two years after the intifada, Israel began issuing residence and work visas to immigrants. Most of them are employed in caregiving, agriculture, and construction (Nathan, 2011). The phenomenon of labor migration is a result of globalization in the labor market, and of the significantly higher minimum wages in countries of the global north compared to wages in the countries of the global south. Most of the migrant caregivers in Israel come from the Philippines and India, less so from Eastern Europe, where they come especially from Moldova and Uzbekistan (Abrahams, 2020). In addition to old people, they also care for adults and children with disabilities.
This thematic issue invites us to engage with ethics in everyday life, and the ways in which spatial planning influences our behavior in space and our moral choices. In this context, we are interested in examining how the design of the typical apartment, an apartment structure that is repeated with small variations in residential apartment buildings in many neighborhoods throughout Israel, has an ethical impact on residents' daily lives. While writers have referred to home interior design from the perspective of power relations (Dovey, 1999; Hillier \& Hanson, 1984), to the best of our knowledge, the Israeli apartment has not been analyzed from the perspective of theories of justice or by examining the concepts of hierarchy and equality.

The relationship between seniors and caregivers is a hierarchic relationship between the former-who are Israeli citizens, employers, and landlords-and the latter-neither Israeli citizens nor permanent residents, dependent on their employers for dwelling and income (Refworld, 1991). Such a relationship is mandated by Israeli law, which requires that immigrant caregivers dwell in their employers' homes (Ben Israel, 2011). Admittedly, power relations may be overturned as the seniors become weaker and more dependent on their caregivers. Typically, rooms in an apartment are unequal in size and location; there is a hierarchical relationship between them. This hierarchy is based on architectural convention rather than the tenants' perceptions. When the residents age, the new use of the apartment, as well as selecting the room where the caregiver will live, is an expression of the ethics of daily life expressed in space, which in turn affects the relationship of care. We address equality and hierarchy by examining architectural qualities such as size, location, and separation/independence.

Analyzing apartment plans reveals that there is one established subtype of apartment design that better meets the needs of old people with caregivers, in which a room and a bathroom is located in the entrance and separated from the other bedrooms in the apartment. Apartments built according to this plan make it possible to create two focal areas in the apartment that meet the needs of both the old person and the caregiver. Implementing Hayden's NonSexist attitude to issues of population aging, we examine proposals for developing the appropriate housing type found in our study, subdividing apartments into a main unit and a secondary unit. These planning proposals have been recommended by an inter-ministerial government team in the Israeli Ministry of Finance (National Housing Headquarters, 2018) and by the Israeli Affordable Housing Center (IAHC), part of the Faculty of Law of Tel Aviv University. IAHC develops new tools in the field of housing to advance policies to help medium and low-income households in Israel secure adequate and affordable housing (IAHC, n.d.; Rabinowitz, 2017). These civil society and government organizations proposed to divide the apartment without examining the proposal architecturally. In this article we discuss architectural and 
technical aspects of expanding a caregiver's unit into a separate unit such as the obligation to build a protected space for each separate unit.

\section{Aging in Typical Apartments}

The population of senior citizens in Israel is above one million. It is estimated that by 2040 that number will be close to $1,900,000$ and represent $14.3 \%$ of the total population (Israel CBS, 2017; Israel CBS, 2019a). The vast majority of senior citizens remain in their homes, and a minority live in institutions or in sheltered housing (either private or public) for those capable of independent living. There are several key housing arrangements for independent senior citizens. Living in their own home, whether owned or rented, is the most common housing arrangement. About $96 \%$ of the older population lives in a community, and $78 \%$ own their apartment. There is both private and public sheltered housing, which is home to some $3 \%$ of senior citizens. A survey conducted by the Ministry for Social Equality found that $22 \%$ of senior citizens would like to live in sheltered housing. Public sheltered housing is intended for those eligible for housing support from the state. About 14,000 senior citizens currently live in public sheltered housing. Private sheltered housing can be a relevant residential solution for many senior citizens but is inaccessible due to the low supply of vacant units relative to the size of the population and high cost to the consumer. According to survey data from the Ministry for Social Equality, $60 \%$ of respondents would consider having a live-in caregiver if their health situation deteriorated (National Housing Headquarters, 2018).

The housing supply, as planned and built in Israel, is characterized by very homogeneous neighborhoods and residential buildings, which consist mainly of 4-5 room apartments with an area of approximately 90-130 square meters per apartment. This means that the supply is suitable for couples with children, even though the structure of households in Israel is much more varied and includes families of many types. Not only are there old people, divorced families, and singleparent families, there are families created by joint parenting, people with special needs, adult couples, multigenerational families, couples without children and nonfamily households (Iplan Studio, 2019). However, until recently, planning institutions focused most residential planning on traditional families. This orientation emerged, among other things, because Israel in its first decades absorbed many immigrants and encouraged childbirth, leading to a high natural population increase. The fertility rate in Israel is one of the highest in the developed world, and it is increasing (in 2018, the total fertility rate was 3.09; Israel CBS, 2020a). Therefore, the need for domestic nursing takes part in the changes in western family structure: The age of marriage is rising, as is the rate of divorce; changes in life expectancy and lifestyle mean that more people are living alone; fami- lies are deconstructed and reconstructed, while the number of single-parent and single-sex families is increasing (Skolnick \& Skolnick, 2007). Family and marriage still have a central place in Israeli society. Nonetheless, as in the rest of the western world, the rate of marriage is decreasing in the Jewish population, and therefore in the general population (Israel CBS, 2019b). The rate of single-parent families in Israel has increased to $12 \%$ (Israel CBS, 2020b).

Different living arrangements and household lifestyles require different, especially smaller, apartments (Iplan Studio, 2019). However, beginning in the mid-nineties, a significant decrease took place in the scope of building small apartments, in particular 3-room apartments (Israel CBS, 2019c). Municipalities are less interested in increasing the reservoir of small apartments, preferring rather to build large apartments since these attract more affluent populations (Gruber, 2014). This trend began to change in 2015, when the state began to encourage the building of small apartments (Israel CBS, 2019c). These small apartments are intended for small households, including seniors. Although some $47 \%$ of households in Israel consist of 1 or 2 people, the supply of new residential construction usually includes only $20 \%$ small apartments. There is a shortage of small residential units and a surplus of large ones (Wenger \& Naor, 2019). Our study shows that apartment size is not the only variable that expedites adapting housing to the needs of multiple population groups. Other architectural variables, and specifically the way in which the older person and caregiver divide the space, also influence the home-care relationship.

The apartments studied here, built in Tel Aviv between the 1960s and the 1980s, are mid-sized and range between 3-4 bedrooms. They are part of apartments buildings type $\mathrm{H}$, which were designed by leading Israeli architects such as Itzhak Yashar (1920-2011), Uri Zrubabel (b. 1941), Itzhak Perlstein (1914-1981), and Aharon Doron (1917-2020). In H type buildings, there are usually four apartments in each floor, organized around a core of stairs and elevators. This arrangement enables each apartment to enjoy three directions of light and air, while mirroring the two adjacent apartments. This typical floor plan is repeated on most floors of the building, except for the last and first floors where there are unique apartments. In recent years, these unique apartments, duplexes for example, replaced the typical apartments in luxurious buildings.

Early $\mathrm{H}$ type apartment buildings were designed in the 1950 s as part of public housing projects for Jewish immigrants to Israel (Efrat, 2004). At the end of the 1970s, residence building in the private sector replaced public residence building. Rationalistic modern design, local conventions, building regulations, and market forces impacted the development of apartment types under the private market. Thus, the evolution of typical apartments stemmed from the capitalist need to sell mass housing for anonymous clients and replaced the uniformity of public housing shaped by ideological motives. 
Target populations of new residential neighborhoodsyoung families with children-perceive the apartment as a safe space that protects the family against external threats, and public space as a familial meeting place (Bar, 2011). Access to center and out-of-town employment and leisure centers, social rapport between residents, and the latter's support of middle-class family lifestyle and values characterize the Ramat Aviv, Ne've Avivim, and Tel Baruch neighborhoods in the north of Tel Aviv (Hatuka \& Bar, 2018), where the interviewees reside. Other apartments in this research were built in the center of Tel-Aviv.

In Israel, income decreases in old age, making seniors financially vulnerable. In 2017 , only about $21 \%$ of seniors participated in the workforce, in comparison to $65 \%$ of the $20-64$-year-old population. $25 \%$ of the over- 65 population was unable to cover their household monthly expenses (Israel CBS, 2019a). Downsizing apartments in old age would improve the affordability of housing for seniors by decreasing the direct and accompanying expenses of housing at later stages of life (Judd, Bridge, Davy, Adams, \& Liu, 2012).

Architect Alexander Klein, who worked in Berlin in 1920-1933, sought to develop apartment plans that met the minimal requirements for living (in German, existenzminimum; Wiedenhoeft, 1985). He contended that, in practice, apartments are divided into two: an area that is active in daytime, and an area that is active in night-time. In daytime, the living room, kitchen, and dining room are active, used for shared living. At night, life moves to the private section: the bedrooms and bathrooms. This division had climatic implications when orientating apartments, towards the sun and winds. Klein emigrated to Israel in 1935 with his western apartment plan (Shadar \& Yacobi, 2014). As a Professor of Urban Planning and head of the Department of Urban Planning at the Technion, beginning in 1951, he trained and influenced students of architecture who went on to design residential buildings (Tidhar, 1956). The design of apartment blocks in Europe in the 1920s also had a direct influence on leading Israeli architects such as Arieh Sharon (Graicer, 2017). Israeli apartments are divided into private areas, consisting of bedrooms and bathrooms, and a public area, consisting of the living room and kitchen. The apartment's public spaces-the living room, the kitchen, and the dining space-are planned to connect in one shared space that is approached directly, without an entrance hall. A small corridor grants access to the bedrooms, the apartment's private rooms. Caregivers are usually placed in a bedroom that was formerly a child's bedroom.

\section{Equality and Hierarchy in Housing and Caring}

The situation in which old people and caregivers, who have relationships of power and dependency, live together invites a new look at the typical apartment from the perspective of perceptions of justice. We are inter- ested in assessing how much freedom tenants in the typical apartment-whose structure they did not designhave and how the relationship between old people and caregivers is shaped by the typical architecture.

Among the ethical concerns raised by the practice of architecture is its physical impact upon people who live in it (Fox, 2006). The design of typical apartments influences dwellers' way of living, without involving them in the planning process. To examine the ethical status of choosing to house the caregiver in a certain place, we must first analyze the apartment and the degree of equality or hierarchy in which it is divided. A hierarchy exists between bedrooms in the apartments when they are not equal in size, their locations differ, they boast an attached bathroom, etc. Typical apartments were planned for families with children, where hierarchy exists between men and women and between adults and children. When the senior or caregiver live in a room that is preferable to the other rooms in the apartment, the division of space in the apartment is not equal. How did the hierarchy of rooms in the apartment affect the creation of unequal relations between seniors and caregivers?

For Rawls, the modern state must be based on justice and equality. By 'justice' he means a fair distribution of resources to all members of the state (Kymlicka, 1990; Rawls, 1971). His theory of justice follows those of earlier thinkers such as Hobbes, Locke, and Rousseau who theorized a primordial 'natural state' in which participants make a rational choice to come together and form a social contract. Shrouded by a 'veil of ignorance,' no person can know in advance what his social status can be once a society is formed, nor does s/he know the skills or resources $\mathrm{s} / \mathrm{he}$ will possess in the future society. Given these primordial conditions, Rawls argues that before forming social contracts, those behind the veil of ignorance most likely grant most of the assets of skills and resources to those with the fewest assets. Inequality is justified only if it favors the weakest in society (Rawls, 1971).

Turiel (1996) places values of equality and rights against social hierarchies, inequalities, and restrictions on freedom that cause conflicts among people. He addresses inequality and injustice as a result of gender relations in the family. We discuss inequalities in hierarchical relations of care. Migrant workers suffer from injustice and discrimination. Human Rights organizations report how the Israeli work laws do not protect the immigrants who work in the caretaking field: Their working day continues throughout all hours of the day. These workers earn minimum wages and are not paid overtime (Ben Israel, 2011). Hierarchy is not necessarily unjust. According to Buchanan, a hierarchical order may be justified if it is based on universal criteria (Buchanan, 2006). When equality of opportunity prevails, for example, some form of competitive process determines individuals' places in the social hierarchy, and all members of society are eligible to compete on equal terms (Arneson, 2015). 
Feminist and cultural perspectives discuss discrimination stemming from unrecognized cultural diversity (Fainstein, 2014). Hayden stresses the need to adapt living environments to working women who also carry the burden for taking care of the family. For her, the separation between home and work leads to a situation in which mothers and house workers (housekeeping and childcare) are not paid appropriately. Women who live in such environments have no work possibilities close to their home. In addition, suburban environments lack public services such as catering, cleaning, childcare, and transportation to support the private home. Although Hayden focuses on gender-based differences and on residence for working women (Non-Sexist city), she also notes the need to integrate the old, the sick, singles, and single parents in the planning of new housing types in ordinary living environments, rather than building separate projects for these groups (Non-Ageist city; Hayden, 1980).

\section{Methodology}

In order to integrate spatial and human knowledge in the research of shared residence of seniors and caregivers, we incorporate three research methods:

1. Qualitative study of test cases: Interviews with old people and caregivers to learn how they live together. Following de Certeau (2011) we observed how seniors and caregivers re-appropriate shared living space. We examine the spatial choices related to this form of cohabitation.

2. Spatial analysis makes it possible to analyze the division of the apartment between old person and caregiver, and to identify different types of apartment. By using concepts of hierarchy and equality, theories of justice and feminist theories are applied to the spatial analysis of typical apartments.

3. Design solutions are at the heart of architecture, but they are less accepted in theoretical research. Hayden's article, as mentioned above, serves as our methodological model for connecting the social analysis of a test case and a proposal for spatial and social change through planning. We propose developing a subtype of apartment design, as identified by our study. Our proposal to modify the typical apartment plan adds concrete social and architectural content to the principled discussion of proposals raised by the planning authorities and social academic organizations in Israel.

We studied six residential apartments of seniors and caregivers in the community, selected from a larger group of cases that included seniors sharing an apartment with a caregiver in private sheltered housing. We documented the apartments, and interviewed five caregivers, the seniors who employ them, and seniors' families. Interviews were matched and compared with spatial analysis of the apartments themselves-using archival sketches of the apartments, drawing detailed plans, and taking pictures of the lived spaces. We made particular note of the changes made in habits of dwelling in standard apartments in order to transform them into spaces of domestic-care work. Likewise, we examined the size, location, and separation of the caregivers' room.

We interviewed three females and two male caregivers, who together care for five females and one male. Of these, only four seniors were interviewed (four females and one male). Once a decision was made to examine a certain apartment subtype, we added one apartment to the research. Due to the old woman's refusal to reveal herself, this example was added without a visit to the apartment and was based on archival drawings of the apartment, and on an interview with the old woman's relative and her cognitive mapping of the apartment. In two other cases, seniors could not be interviewed due to their deteriorated cognitive state. Instead, interviews were held with close family members: a daughter and a son. One interview was held after the old person had passed away. Other seniors were in a relatively good cognitive state. At the time of the interviews, most caregivers had spent several months (up to seven years) living in the shared residential space with their employers. When we addressed cultural differences, regarding cooking, between seniors and caregivers who come from South Asia, we resorted to interviews of caregivers and seniors who lived in two apartments in sheltered housing.

The caregivers we interviewed came to Israel from the Philippines, India, and Sri Lanka. Most of them studied nursing in their country of origin and paid an agency fee to come to Israel. Many have children in their home countries, who are cared for by members of their family. They spend most of their time in the old person's home, except for short outings during the week and one day off on the weekend. Some of them rent (or rented in the past) shared apartments in south Tel Aviv with other caregivers for use during their days off. They have friends and sometimes spouses in Israel; occasionally their friends visit them in the older person's apartment. Some also belong to communities of migrants from their country of origin residing in Israel, and hold religious ceremonies and celebrate national holidays together (interviews with E., C., A., A., and H. October 2018-June 2019; Liebelt, 2011). We interviewed caregivers in their place of work, sometimes in the presence of their employers. This posed an ethical limitation. Despite our attempts to interview them separately, only three interviews were conducted in a separate room, the senior unable to listen in. Appositely, the fact that most seniors agreed to be interviewed suggests the cases under study consisted of spacious-enough shared residences and good-enough relationships, rather than abusive or oppressive seniorworker relationships.

Likewise, additional interviews were conducted with six relatives of seniors or with caregivers, without analyz- 
ing their apartments and with five professionals from relevant fields: a social worker, two members of NGOs, one working on behalf of migrant workers and the other serving senior social housing, an architect who designed one of the apartment buildings where the seniors live, another architect who specializes in renovation apartments in $\mathrm{H}$ type buildings, and a social planner who advises the Ministry of Construction and Housing on age-friendly cities. We examined our findings looking for equality and hierarchy in shared residency. Likewise, we implemented Hayden's social perspective in studying suggested apartment design for senior care.

\section{Architectural Design and Moral Choices in Housing and Caring}

Following de Certeau (2011) - the French Jesuit and scholar known as the philosopher of everyday life and whose work combines history, psychoanalysis, philosophy, and the social sciences-we observed tiny everyday behaviors and creative tactics through which seniors and caregivers re-appropriate shared living space. In most cases, seniors had lived in the same apartment for decades. They renovated it well before reaching old age but changed its usage at later stages of life. In two case studies, seniors stopped using the main bedroom. Following her husband's death, T. moved to the children's unit (interview with Z., November 2018), while A. preferred to sleep with her legs raised on an adjustable armchair in the living room (Figure 1, interview with A., November 2018). Another senior, O., stopped using the room in the attic where her husband used to listen to mu- sic because of the painful memories it evoked (interview with O., November 2018).

Since no major changes were made in their apartment as they entered the stage of shared residency with a caregiver, the central ethical decision seniors who participated in this research made was to determine the caregivers' living space and the room the latter would live in. In each case it appears that, while architects planned the residence buildings decades ago, in the transition to domestic care the moral agency moved from the architect-who planned the building meant for families with children-to the elderly who make new use of the spaces as a space for caregiving.

The room's size, location, and accessibility to a bathroom are all seemingly neutral spatial variables, which are not charged by social values. However, the discussion of certain spaces, such as the parents' bedroom, demonstrates that the planned usage of these spaces is not devoid of social and cultural meaning.

\subsection{The Size of the Caregiver's Room}

Judy Attfield describes how concepts of open plan and social change led to renouncing the idea of "a hierarchy of rooms that divides the servants' quarters from those of the employers" (Attfield, 1999, p. 76) in British modern apartments since World War II, thus increasing the social equality in house design.

In Israel, apartments built in the 1930s in the international style had several equal-sized rooms, including the living room. However, since the 1950s a distinction has been made between the size of rooms, and the size of

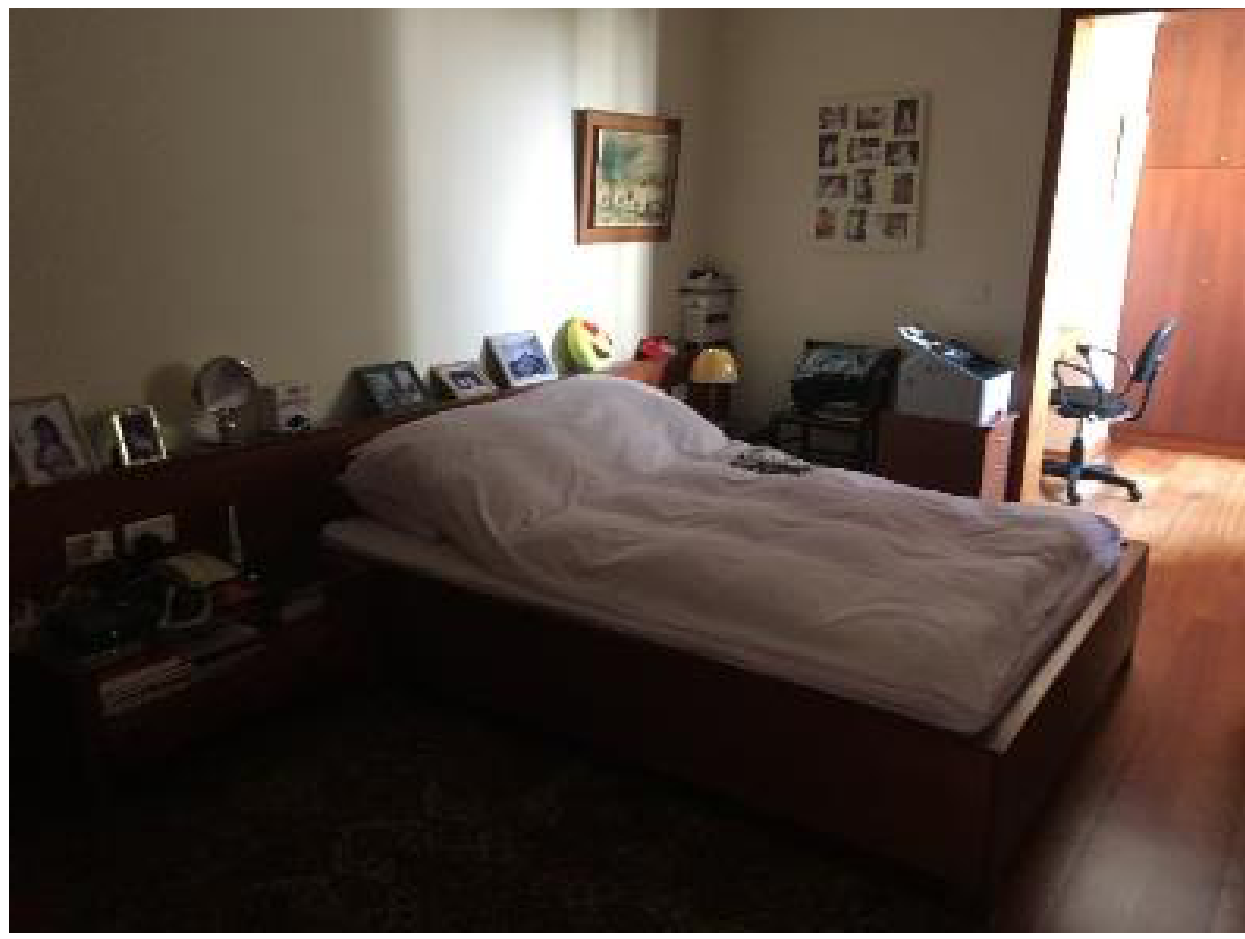

Figure 1. An unused bedroom, apartment of $A$. and T. 
the living room has increased. In the 1970s, one of the bedrooms grew in size in relation to the others, and became the parents' bedroom (Amir, 2001).

The Planning and Building Law determines the minimal size of a room in the apartment, no less than eight square meters (Nevo, 1970, 1980, 1990). However, according to Tula Amir, in the private housing marketwhere promoters are pushed to maximize the number of rooms in an apartment- "the minimum becomes the standard" (Amir, 2017, p. 92). In any case, these rooms tend to be twice the size of what the Israeli regulations require an employer to provide a migrant worker-a sleeping area of at least four square meters (Population and Immigration Authority, 2018). But still, most of them live in a room smaller than the parents' bedroom, thus manifesting an unequal relationship between them and their employers. Other considerations are involved in this choice as well. The preference for a particular room is not only according to its size, but sometimes according to its previous use: The caregiver's room could be the room left unused; T. chose the smaller room, as mentioned above, so that she could avoid difficult memories of her husband's illness; while $\mathrm{H}$. chose to stay in her smaller room, which is indeed larger than that of the caregiver and didn't move to her late husband's room which was located in the parents' unit (Figure 2; Interview with Z., November 2018; Interview with N. May 2019).

\subsection{The Location of the Caregiver's Room}

Two different locations for the caregiver's room were found in the research. The first is in one of the children's rooms, in the bedroom area of the typical apartment layout (Figures 3-5). The other is at the entrance of the apartment, made possible by an apartment subtype, in which one room is separated from the other bedrooms in the apartment (Bar, 2011; Figures 2 and 6). Such a room at the entrance had, from time to time, served R. and R.'s son, who lives abroad. The senior couple chose to house the caregiver in this room rather than in a smaller halfroom in the apartment, in order to provide him with a separate unit. We interpret this choice in old age as an expression of the couple's attempt to benefit caregivers through the use of apartment resources (Figure 7).

We argue that this variation of the apartment plan can take on an important role for both seniors and caregivers as life expectancy grows. The apartment's location in the floor plan shows that the bedroom area benefits from more natural light than the room at the entrance, since this room is attached to the walls of the adjacent apartment (Figure 7). Nevertheless, its proximity to the entrance enables the caregiver to enter and leave without interruption or supervision. This location meets the needs of both senior and caregiver for spatial separation; at least in the first stages of shared living, before the senior's condition deteriorates.

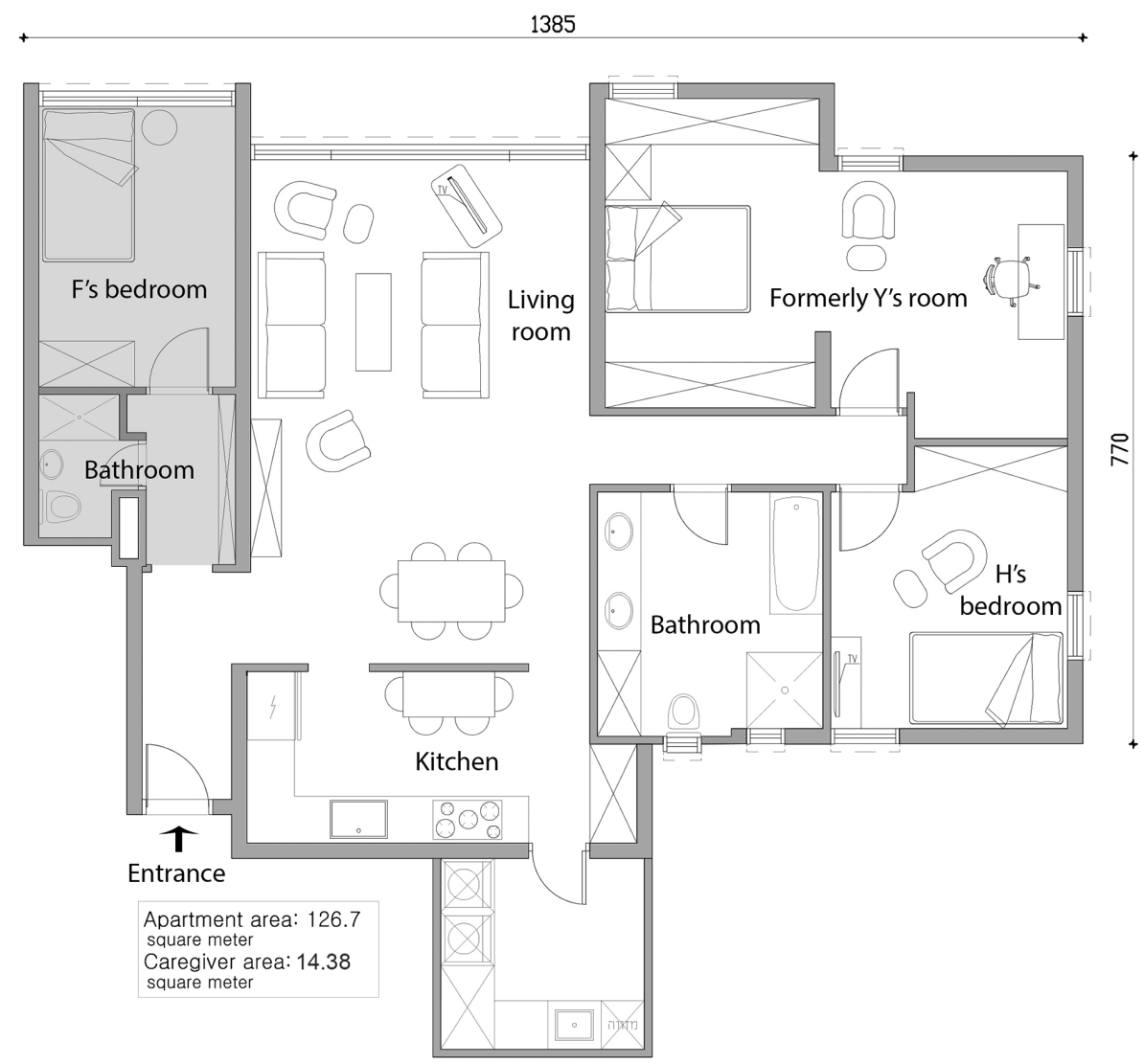

Figure 2. Apartment of H. and F., Tel Aviv. Graphics by Shahar Malka. 


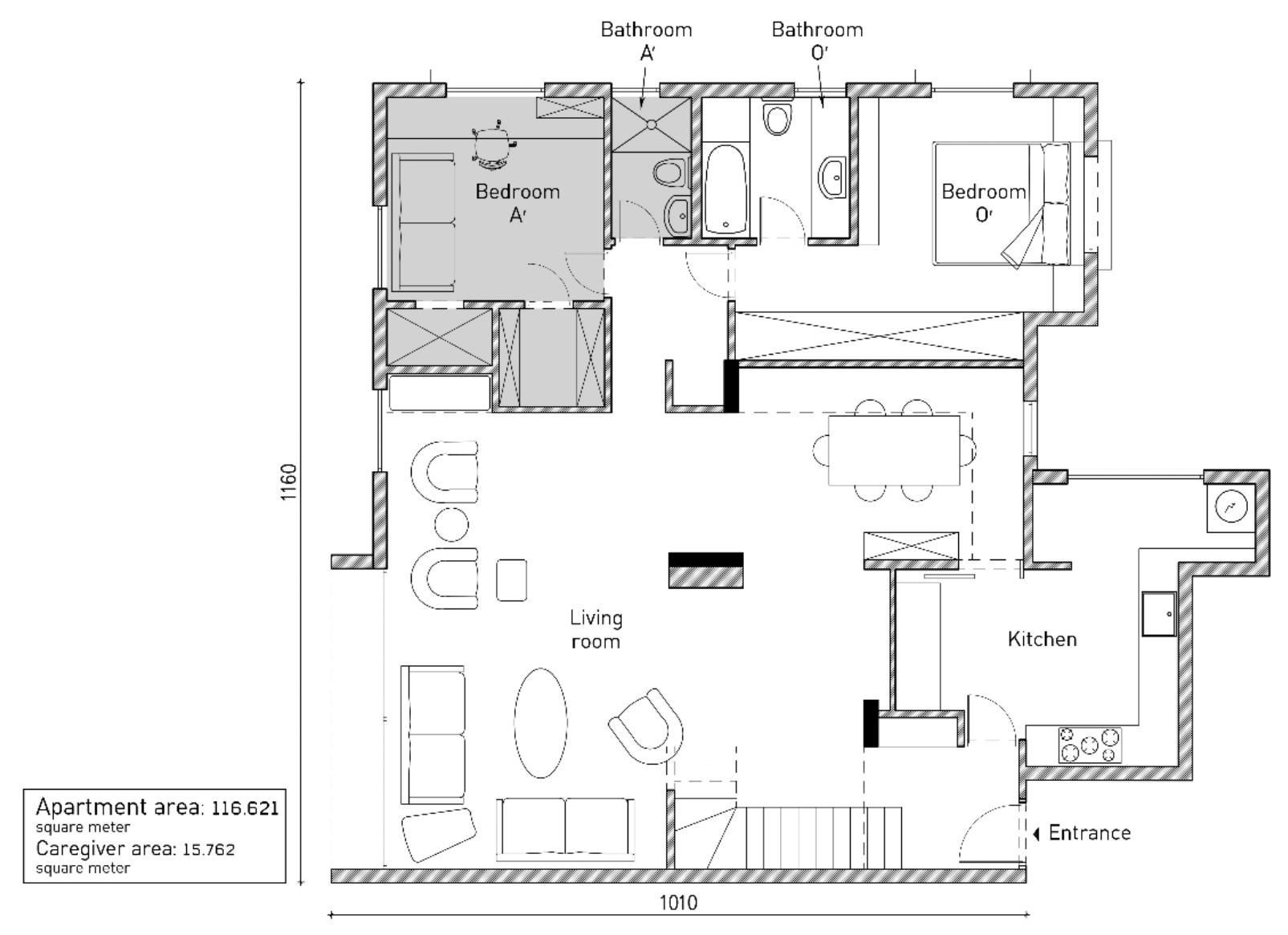

Figure 3. Apartment of O. and A., main floor (upstairs is the roof balcony). Graphics by Ira Elon.

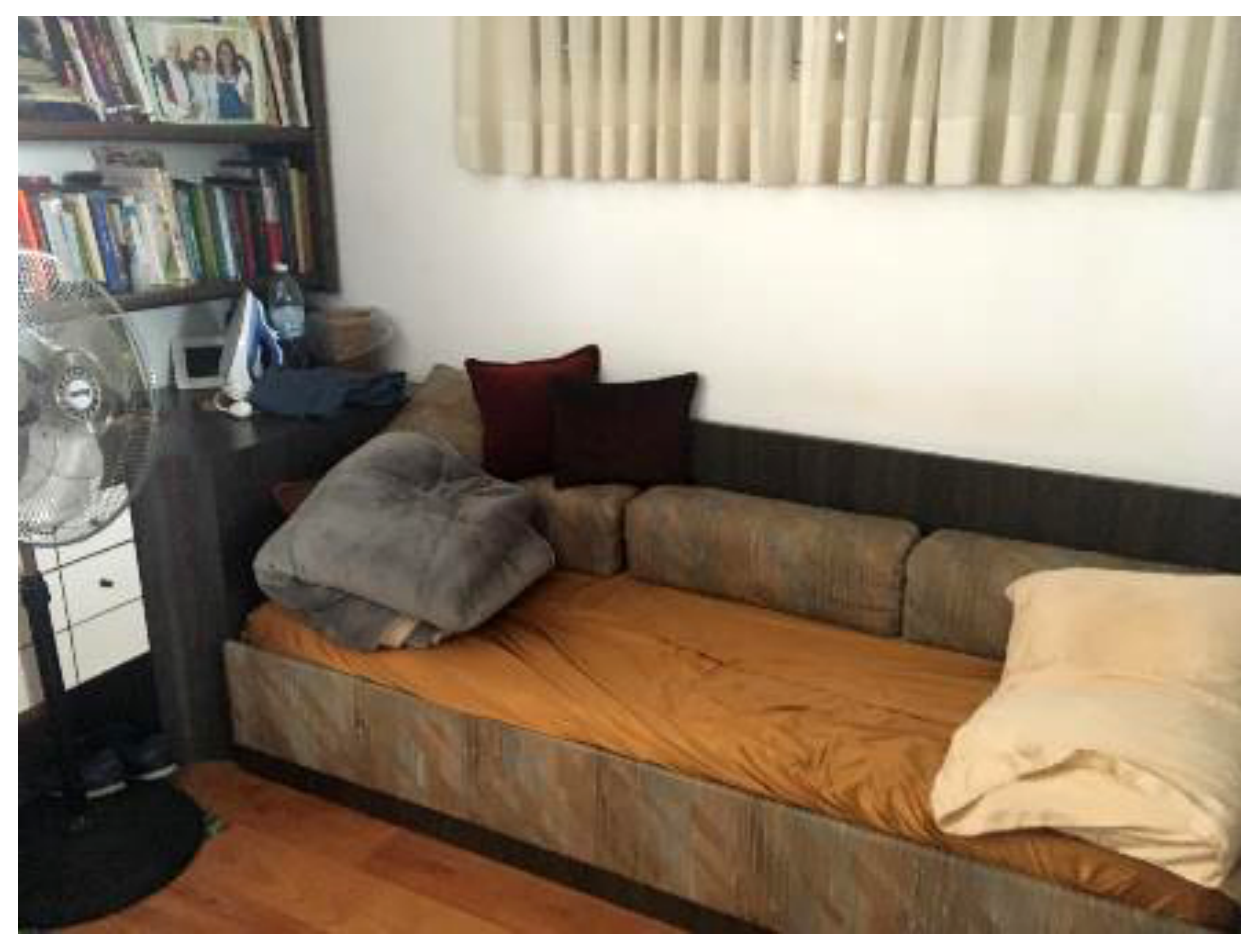

Figure 4. A.'s room, apartment of O. and A. 


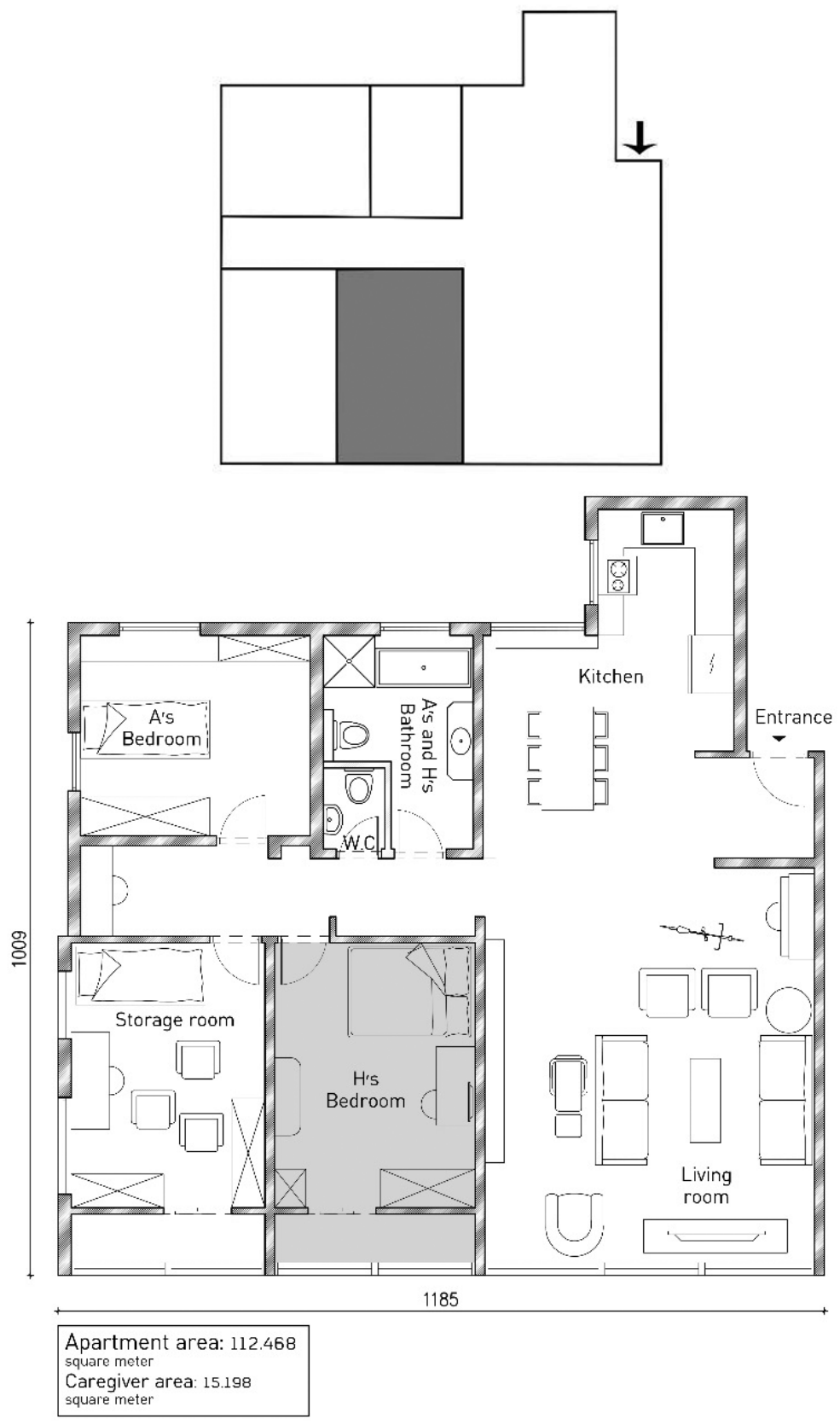

Figure 5. Location of caregiver's room, apartment of A. and H. Tel Aviv. Graphics by Shahar Malka.

\subsection{Independence and Separation of Units in the Apartment}

When the service areas-including those shared by several bedrooms in the private area of the apartment-are brought into the bedroom, it becomes an independent unit that sustains more domestic needs and manifests a hierarchy between the rooms of the typical family apartment (Figure 8).

A central example of this hierarchy is the development of the separate parents' unit in the 1980s with a bathroom and a walk-in closet. In English, it is called the master bedroom - the main bedroom or the room of the master of the house (Thompson, 1998). In most of the apartments we examined, a parents' bedroom-as it is called in Hebrew - was added in a later renovation of the apartment. Three decades later, the caregiver's room at the entrance to the apartment also becomes a separate living unit with a separate bathroom and toilet, and a manifestation of hierarchy in the use of the apartment in old age.

The development of the parents' unit is a manifestation of a rise in living standards, hedonism, and an aspiration to prestige in the U.S.A. (Vollmer, Schulze, \& Chebra, 2005) and Israel alike, as well as global inspirations over the design of apartments in Israel in the 1980s (Regev, 2001). For old people, however, whose range of movement becomes restricted and who spend more hours a 

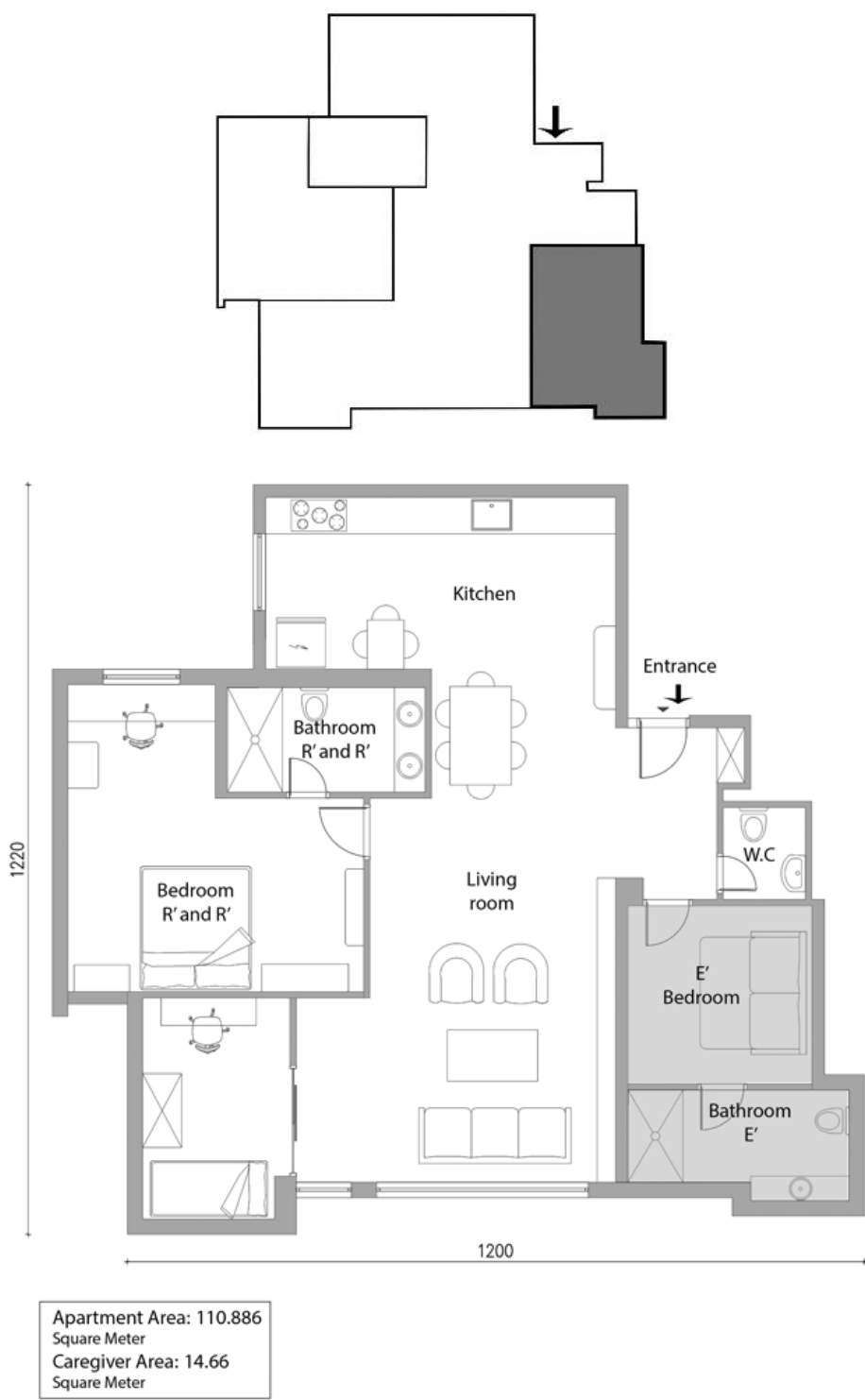

Figure 6. Location of caregiver's room, apartment of R., R. and E. Graphics by Shahar Malka.

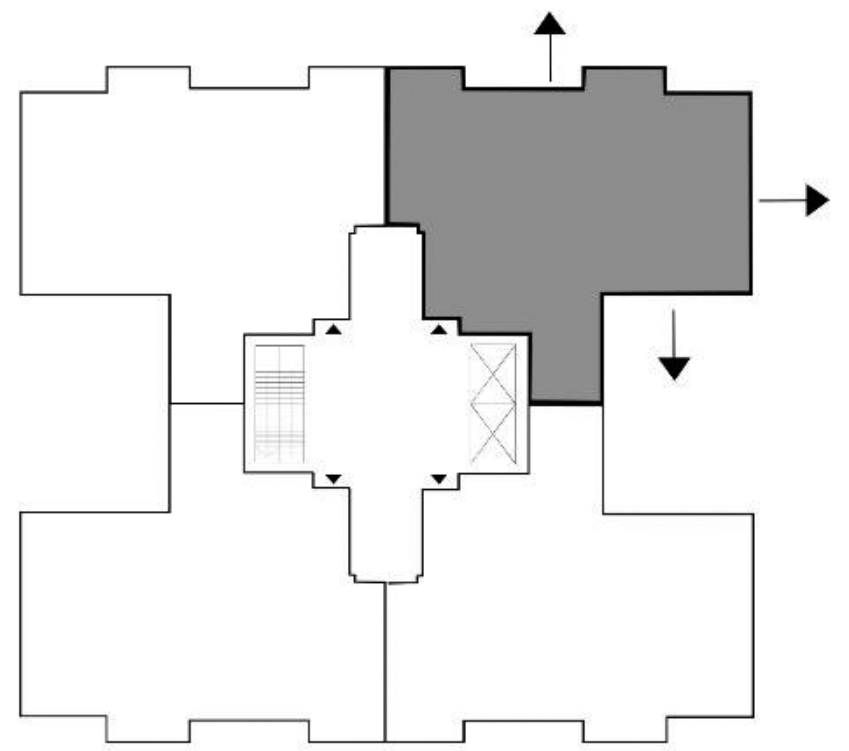

Figure 7. Location in floorplan of the apartment of H. and F. Graphics by Shahar Malka. 

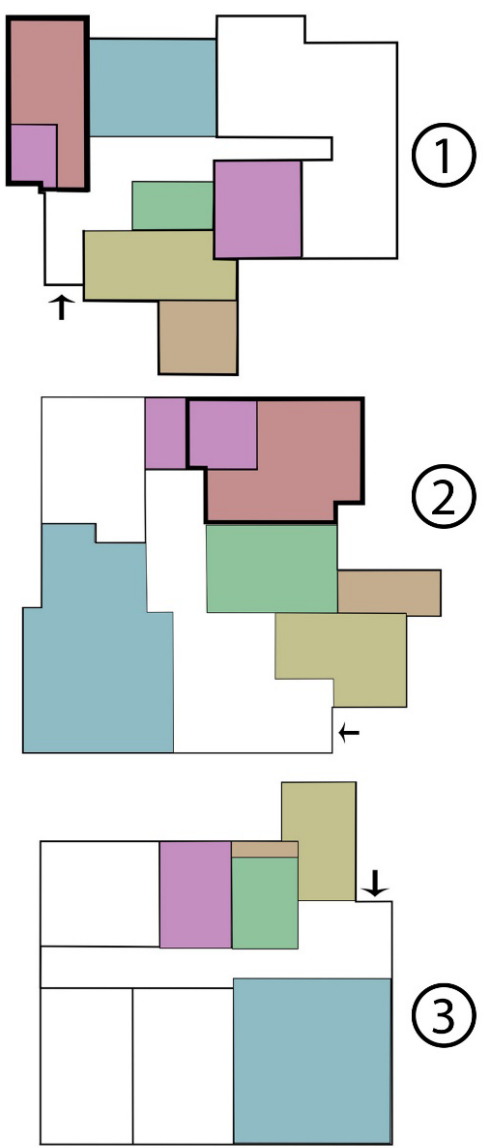

(1) Apartment of $\mathrm{H}$. and $\mathrm{F}$.

(2) Apartment of O. and A.

(3) Apartment of A. and $\mathrm{H}$.

(4) Apartment of R. R. and E.
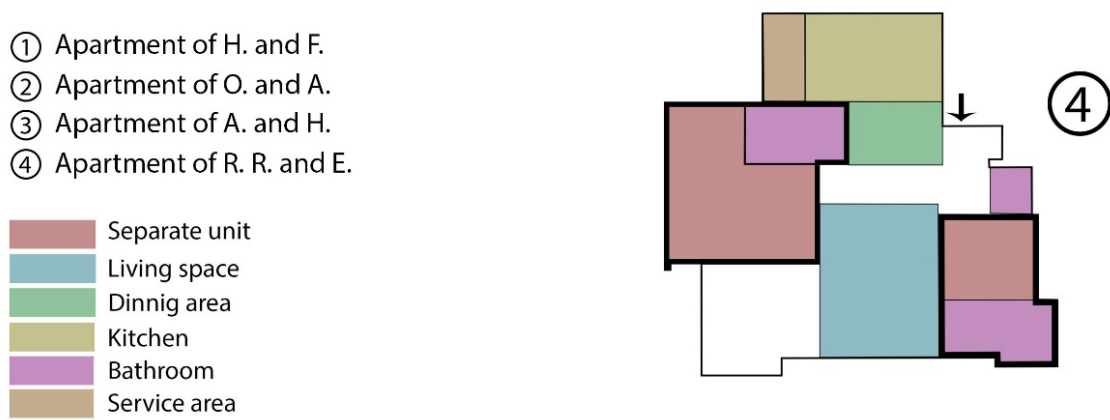

Figure 8. Independence and separation of units in the apartments. Graphics by Shahar Malka.

day in the bedroom, a proximity of the toilet to their bed is no longer considered a luxury.

It can be contended that separating the caregiver's unit increases further the inequality in the apartment. However, following Rawl's Difference Principle, which determines that inequality is justified when serving the weaker members of society, expanding a unit in the apartment for the weaker resident is justified. Acknowledging the caregiver's weakened status, we propose that the caregiver's unit be further expanded.

\section{Housing as Care: A Suggested Apartment Layout}

Most home owners do not want to leave their apartment in old age (interview with R. Ben-Nun, adviser to the ministry of construction and housing, June 2020;
National Housing Headquarters, 2018). Can it be adapted to their changing needs? Hayden proposed that large private homes in suburban neighborhoods in the U.S.A. should be divided into several small units that would provide housing for singles and seniors (Hayden, 1980). Small temporary and inexpensive units, used to house seniors and relatives in suburban private lots in Australia, are called 'Granny Flats' (Folts \& Muir, 2001). In private houses in Israel, too, there are frequently sub-units in the basement with a separate entrance. Planning law has been amended to allowed to split apartments in detached houses (Knesset, 2017).

A separate private unit makes it possible to create additional distinctions within the residence apartment: a distinction between work and living, between adolescents and children, and between caregivers and family 
members. In order to increase the equality and independence of caregivers and seniors, architect M. Kaplan, who specializes in renovation of apartments in $\mathrm{H}$ type buildings, offered upon our request to enlarge the entrance room of an apartment built in Tel Aviv in the 1990s into a small, separate unit that includes a bathroom, a kitchenette, and a larger living area (15 square meters). A separate kitchen could meet cultural differences between the food caregivers eat and the one seniors eat-the caregiver S. doesn't prepare her employer kosher food and the senior $M$. said she could benefit from a closed kitchen to avoid cooking smells (interview with M. and S. in 2018 and 2019 respectively). To com- pensate for the reduction in living space, one of the bedrooms-which served one of the couple's child in an earlier phase-will be eliminated (Figure 9).

Ronny Bar found families with children satisfied with the typical apartment in new neighborhoods, except for residents who wanted studies, a larger parents' unit, and a unit for adolescent children (Bar, 2011). Thus, the separate living unit will serve various purposes, according to the residents' stage of life: a room for an adolescent, a room for visiting grandchildren, and accommodations for various work-from-home arrangements, which could serve for isolation purposes during an epidemic as well.

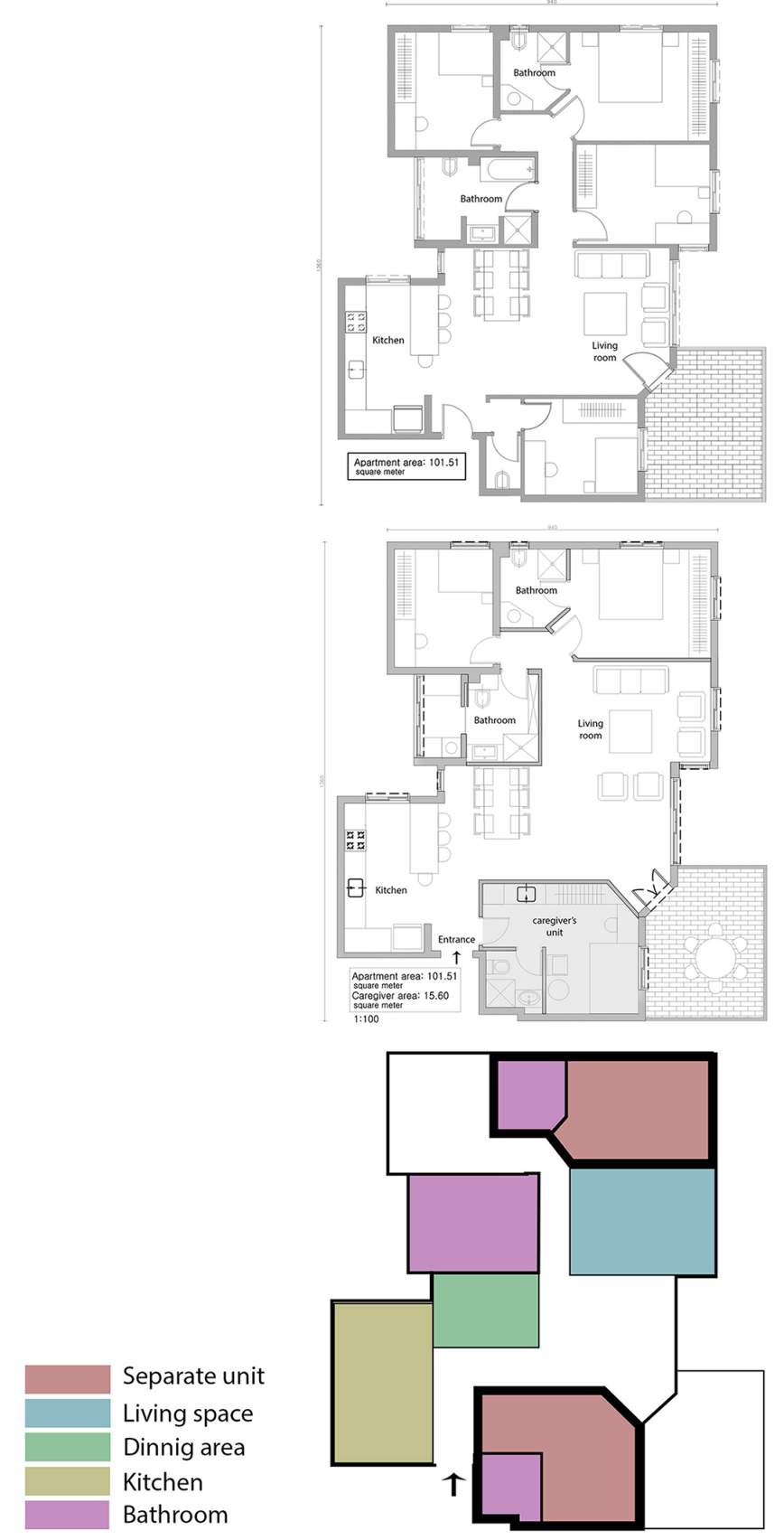

Figure 9. Architect M. Kaplan's proposed layout of an apartment in Tel Aviv. Graphics by Shahar Malka. In the figure, see the original plan above and suggested plan below. 
The suggested sub-units would be located in all residential areas where senior citizens live, including in residential buildings in the most expensive neighborhoods in Israel. When the old person lives in the main apartment and the caregiver lives in the secondary unit, the independence, equality, and privacy of both parties would increase at no additional cost.

In light of the current and expected increase in the older population, an inter-ministerial government team in the National Housing Headquarters suggests a more radical solution. Their report concluded that it is necessary to formulate solutions and increase the inventory of planned and existing apartments that meet the needs of senior citizens who are interested in remaining in their homes. The team recommended allowing existing apartments to be subdivided in ways that would facilitate the caregiver their own unit within the apartment, which provides a degree of privacy. Subdivision could offer opportunities for additional income (National Housing Headquarters, 2018). Before the life-stage of requiring homecare, seniors would be able to rent the units on the free market to individuals, to small households, or to Israeli caregivers who are not legally required to reside with the person for whom they are caring. The idea was developed by the IAHC for apartments in old residence neighborhoods that are in the process of urban renewal (Rabinowitz, 2017; interview with M. Rabinovich, representative of the Affordable Housing Center, June 2019).

According to the IAHC, the accompanying apartment (called in Hebrew a diurit, a special kind of an apartment), will be planned in advance as a sub-apartment within the larger apartment-with the possibility to split it physically, without any need for permits, into two separate apartments. Thus, the accompanying apartment solution does not require a move out of the original apartment. Instead, the senior can split the apartment and rent the smaller unit out, remaining at home in the bigger unit, while improving his or her income in old age. The IAHC representative suggested this approach as a tool for keeping the older population in the neighborhood, without any specification on an architectural scale in the Tel-Aviv Ne've Ofer neighborhood's urban renewal (Lazar, 2018).

We emphasize the important use of the accompanying apartment that arises from our research: It will be able to house seniors' caregivers. Thus, the accompanying apartment will provide a living arrangement for seniors who require everyday help despite still being relatively independent, increasing caregivers' equality.

Dividing the apartments raises economic and planning questions. New building policy will be needed to allow flexible splitting of apartments and enlarging the amount of housing units in a building project (National Housing Headquarters, 2018; Interview with architect Uri Zrubabel, December 2019). Small independent apartments require by law a minimal area of 30 square meters (Nevo, 2013). However, the Israel Planning Administration recently suggested reducing minimal apartment areas, starting at 15 square meters (Melniki, 2020). Splitting standard apartments into two units requires adding a protected space against bombing and missiles, according to civilian protection laws in Israel (Civilian Defense Regulations, 1990). This is a serious limitation that is imposed on the planning of small apartments. However, the use of a shared protected space on every floor-instead of a private one, as was customary in the past-is an opportunity to create shared spaces on every floor that can be used in favor of the senior residents, caregivers, and other residents. This refers back to Hayden, who suggested creating a mixture of uses between residence and services in private spaces of a suburban neighborhood (Hayden, 1980). Other regulations that exist, but are about to expire, allow for additional $30 \%$ in the number of housing units without adding to the total building area (Fialkoff, Cohen, \& Lindenbaum, 2016).

\section{Conclusion}

Examining spaces shared by seniors and foreign domestic workers in relation to the needs of a growing elderly population, this study showed that standard architecturecatering to young families - can be measured according to its hierarchy and equality, and to the ethical effects of these qualities among senior-caregiver relations. The article examined justice on several levels: in the architectural design of the apartment, in the choices of elders about where to house caregivers, and in the potential of design proposals of architects and planning policy recommended by government teams, civil society organizations, and academia to improve housing conditions of caregivers of old people. These architectural solutions cater to the social needs presented in the earlier sections of the article.

Variations of the typical apartment, built in Tel-Aviv in the 1960s-1980s, meet better the needs of equality and separation, and may allow both seniors and caregivers varying degrees of interdependence and autonomy. Inspired by Hayden's question-What would a nonsexist city look like? - we ask what would a non-ageist residence look like: a residence that does not discriminate against seniors, but rather adapts itself to their needs. Hayden criticized the suitability of the American suburban private home for the needs of working women. She described a separation between women's work environments in the city, their living environment in the American suburb, and wrote against the privatization of housework-a situation in which the work of child caregivers and cleaners is carried out without wages or at a low salary. Four decades later, we examine the integration of home and work for those who provide care for seniors, when welfare policies encourage aging in place and privatizes nursing solutions in old age.

Against values of sharing between caregivers and seniors, and values of the apartment's familial nature, stand values of independence, separation, and auton- 
omy of the caregivers. The bipolar transformation of the apartment, with two focal points of importancethe caregiver's unit and the parents' unit (apartment 4 in Figure 8 and Figure 6)-manifests a change in the family structure and the transition to seniors living with caregivers.

The planning proposals examined here show potential use of flexible accompanying living units, according to the needs of seniors. These units might meet other families' needs as children grow up and adults grow old. When accompanying living units are to serve the housework of immigrant caregivers within the apartment building, they will turn the standard apartment building from one-dimensional-serving only Israeli families with children-into an inclusive residence for seniors and immigrant caregivers who lack citizen status.

\section{Acknowledgments}

Research for this article was supported by the Centre for Architectural Research and Development, Technion Israel Institute of Technology, by IIAS Institute for Advanced Studies, and by a 2020 Ministry of Housing research grant for the National Building Research Institute. We would like to thank the editors and reviewers for their thoughtful contributions. Our gratitude also goes to the researchers Dr. Chen Misgav, Dr. Naama Meishar, Dr. Gabrielle Schaad, Dr. Sigal Eden Almogi; and the architects Uri Zerubbabel, Michal Kaplan and landscape architect Tsufit Tuvi for their suggestions and comments.

\section{Conflict of Interests}

The authors declare no conflict of interests.

\section{References}

Abrahams, M. (2020). Netunei zarim beisrael [Data on foreigners in Israel]. Jerusalem: Population and Migration Authority, Policy Planning Division. Retrieved from https://www.gov.il/BlobFolder/generalpage/ foreign_workers_stats/he/sum_2019.pdf

Amir, T. (2001). Kav 5-Hebetim hevratiim baadrichalut hisraelit [Route no.5: Social aspects of Israeli architecture] (Unpublished Master dissertation). Tel Aviv University, Tel Aviv, Israel.

Amir, T. (2017). Granit porcelanit [Granit porcelain]. In T. Amir (Ed.), Tamrurot: Feminism vemerhav beisrael [Tamrurot: Feminism and space in Israel] (pp. 84-101). Tel Aviv: Xargol Books and Modan Publishers.

Arneson, R. (2015). Equality of opportunity. In E. N. Zalta (Ed.), Stanford encyclopedia of philosophy. Retrieved from https://plato.stanford.edu/archives/sum2015/ entries/equal-opportunity

Assiskovich, S. (2017). Hebetim bebituh siud 2017 [Aspects of nursing insurance 2017]. National Insurance Institute of Israel. Retrieved from https://www.btl.
gov.il/Publications/survey/Pages/seker_304.aspx

Attfield, J. (1999). Bringing modernity home: Open plan in the British domestic interior. In I. Cieraad (Ed.), At home: An anthropology of domestic space (pp. 73-82). Syracuse, NY: Syracuse University Press.

Bar, R. (2011). Kehilot megudarot lelo gderot: Tichnun veorchot haim besvivot megurim hadashot [Gated communities without gates: Planning and lifestyle in new residential environment] (Unpublished Master dissertation). Tel Aviv University, Tel Aviv, Israel.

Ben Israel, H. (2011). Shetah hefker: Mehagrot avoda bisrael 2001 [The no-man's land: Migrant workers in Israel 2011]. Tel Aviv: Kav LaOved Workers Hotline. Retrieved from https://www.kavlaoved.org.il/ wp-content/uploads/2011/03/Shetach-Hefker2011.pdf

Buchanan, J. M. (2006). Equality, hierarchy, and global justice. Social Philosophy and Policy, 23(1), 255-265.

de Certeau, M. (2011). The practice of everyday life (S. F. Rendall, Trans.). Berkeley, CA: University of California Press.

Doron, I., Bar, L., Adut, R., \& Gan-Mor, G. (2016). Bituh siuud tziburi: Hzorech bereforma hakikatit [Public nursing insurance: The need for legislative reform]. Haifa and Tel Aviv: Haifa University and the Association for Civil Rights in Israel. Retrieved from https://law.acri.org.il/he/wp-content/uploads/ 2016/06/reform.pdf

Dovey, K. (1999). Framing places: Mediating power in built form. London and New York: Routledge.

Efrat, Z. (2004). Haproyect haisraeli bniyah veadrichalut 1948-1973 [The Israeli project: Building and architecture, 1948-1973]. Tel Aviv: Tel Aviv Museum of Art.

Fainstein, S. S. (2014). The just city. International Journal of Urban Sciences, 18(1), 1-18.

Fialkoff, H., Cohen, A., \& Lindenbaum, A. (2016). Tamhil diur betel Aviv, clei ezer leavodat hazvatim [A housing mix in Tel Aviv, aids for team's work: Strategic planning unit of engineering administration]. Tel Aviv: Tel Aviv-Jaffa Municipality.

Folts, W. E., \& Muir, K. B. (2001). Housing for older adults: New lessons from the past. Research on Aging, 24(1), 10-29.

Fox, W. (2006). Architecture, Ethics, and the Theory of Responsive Cohesion. In Proceedings of the Australian and New Zealand architectural Science Association (pp. 1-8). Retrieved from http://anzasca. net/wp-content/uploads/2014/08/ANZAScA2006_ Warwick_Fox.pdf

Graicer, I. (2017). Mehashcuna el hashicun: Hahityashvut haironit shel hapoalim beretz Israel veshorasheha harayoniim 1920-1950 [From neighbourhood to housing estate: The urban settlement of the labor movement in the land of Israel and its ideological sources, 1920-1950]. Haifa: Paredes.

Gruber, N. (2014). The housing market in Israel (Policy Paper No. 2014.08). Jerusalem: Taub Center for Social Policy Studies in Israel. Retrieved from http:// 
taubcenter.org.il/wp-content/files_mf/theisraeli housingmarket2014english57.pdf

Hatuka, T., \& Bar, R. (2018). The city-region and the challenge of its representation: The hierarchical network of newly built neighborhoods in the Tel Aviv Metropolitan Area. Environment and Planning A: Economy and Space, 50(4), 869-894.

Hayden, D. (1980). What would a non-sexist city be like? Speculations on housing, urban design, and human work. Signs, 5(3), 170-187.

Hillier, B., \& Hanson, J. (1984). The social logic of space. Cambridge: Cambridge University Press.

lecovich, E. (2011). Metaplim zarim besiud kshishim: Sugiot bamechkar, bamdeniut vebapractika [Foreign caregivers in elderly nursing: Issues in research, policy and practice]. In E. lecovich (Ed.), Tipulei bait bezkenim hamugbalim betifkudam: Sugiot, sherutim, tochniot [Home care for frail older adults: Issues, service and programs] (pp. 311-327). Jerusalem: JDC-Israel Eshel.

Iplan Studio. (2019). Project ha'adam bamercaz- heker tamhilo diur [The Human at the Center ProjectHousing Mix Research]. Tel Aviv: Israel Planning Administration. Retrieved from https://www.gov.il/he/ Departments/Guides/iplan_studio?chapterIndex $=2$

Israel Affordable Housing Center. (n.d.). Homepage. Israel Affordable Housing Center. Retrieved from https://www.israhc.org/home-english

Israel Central Bureau of Statistics. (2017). Tahazit uchlusiat Israel ad shnat 2065 [Projections of Israel population until 2065]. Jerusalem: Israel Central Bureau of Statistics. Retrieved from https://www.cbs.gov.il/he/ mediarelease/DocLib/2017/138/01_17_138b.pdf

Israel Central Bureau of Statistics. (2019a). Yom haezrah havatik habein leumi. Mivhar netunim al ezrahei Israel havatikim bnei 65 vamala [International day of senior citizens. Selected data on various topics regarding Israeli senior citizens aged 65 and over]. Jerusalem: Israel Central Bureau of Statistics. Retrieved from https://www.cbs.gov.il/he/ mediarelease/DocLib/2019/301/11_19_301b.pdf

Israel Central Bureau of Statistics. (2019b). Leket netunim leregel tu beav tashat [Selected data on the occasion of "Tu beav" 2019]. Jerusalem: Israel Central Bureau of Statistics. Retrieved from https:// www.cbs.gov.il/he/mediarelease/DocLib/2019/244/ 11_19_244b.pdf

Israel Central Bureau of Statistics. (2019c). Binuy diur venadlan, shnatom statisti leisrael 2019, Dirot lefi sug binyan, mispar hadarim badira veshlav bniyah, luh 20.9 [Housing and real estate construction, statistical yearbook of Israel 2019, apartments by type of building, number of rooms in the apartment and construction phase, board 20.9]. Jerusalem: Israel Central Bureau of Statistics. Retrieved from https://www.cbs.gov.il/he/publications/doclib/ 2019/20.\%20shnatonconstruction/st20_09x.pdf Israel Central Bureau of Statistics. (2020a). Leket ne- tunim leregel yom haisha habein leumi [International Women's Day 2020]. Jerusalem: Israel Central Bureau of Statistics. Retrieved from https:// www.cbs.gov.il/he/mediarelease/DocLib/2020/067/ 11_20_067b.pdf

Israel Central Bureau of Statistics. (2020b). Mishpahot beisrael, leket netunim leregel yom hamishpaha [Family Day-Families and households in Israel]. Jerusalem: Israel Central Bureau of Statistics. Retrieved from https://www.cbs.gov.il/he/ mediarelease/DocLib/2020/053/11_20_053b.pdf

Judd, B., Bridge, C., Davy, L., Adams, T., \& Liu, E. (2012). Downsizing in later life: Myths and realities concerning the movement of older people in the housing market (Report for the housing and living conditions of aged populations workshop [WS15]). Delft: ENHR. Retrieved from http://www.enhr.net/ documents/2012\%20Norway/WS\%2015-Judd.pdf

Katan, J. (2002). Tahalichei hahaafrata bemaarechet harevaha lezkenim: Tmunat mazav velekahim rishonim [Privatization processes in the social services system for the elderly: Update and preliminary lessons]. In I. Brik (Ed.), Hapolitica shel hazikna: Hauclusia hamevugeret beisrael beseder adifuyot leumi [The politics of aging: The elderly population in Israel and the national set of priorities] (pp. 77-110). Tel Aviv Hakkibutz Hameuhad.

Knesset. (2017). Amendment 117, Temporary Order, Israel Planning and Building Law, 2017. Retrieved from https://main.knesset.gov.il/Activity/Legislation/ Laws/Pages/LawBill.aspx?t=LawReshumot\& lawitemid $=579107$

Kymlicka, W. (1990). Contemporary political philosophy: An introduction. Oxford: Oxford University Press.

Lazar, D. (2018). Shcunat Neve Ofer, mismah mesdiniut [Neve Ofer neighborhood, policy document]. Tel Aviv: Danny Lazar Architects.

Liebelt, C. (2011). Caring for the 'Holy Land': Filipina domestic workers in Israel. New York, NY, and Oxford: Bergham Books.

Melniki, G. (2020, August 7). Hayom Sheahrei [The day after]. The Marker, pp. 38-39.

Nathan, G. (2011). Lo Israelim beisrael (zarim, ovdim zarim, plitim, mistanenim, vemevakshei miklat, tmunat mazav), 2010-2011 [Non-Israelis in Israel (foreigners, foreign workers, refugees, infiltrators and asylum seekers) situation, 2010-2011]. Jerusalem: Knesset, Research and Information Center.

National Housing Headquarters. (2018). Doh hazevet habein misradi lekidum pitronot diur mugan leezrahim vatikim [Inter-ministerial team report for the promotion of sheltered housing solutions for senior citizens]. Jerusalem: Ministry of Finance. Retrieved from https://www.gov.il/BlobFolder/ reports/doch_kidum_pitronot_diyur_migun_ leezrachim_vatikim_2018/he/documents_doch_ kidum_pitronot_diyur_migun_leezrachim_vatikim_ 2018.pdf 
Nevo. (1970). Application for a Permit, its conditions and fees. Retrieved from https://www.nevo.co.il/ law_html/law01/044_046.htm\#hed21

Nevo. (1980). Minimum area of building parts and minimum width between walls. Israel planning and construction regulations 1980 . Nevo. Retrieved from https://www.nevo.co.il/law_html/law01/044_ 046.htm\#hed21

Nevo. (1990). Construction of shelters, Israel civilian defense regulations, 1990. Nevo. Retrieved from https://www.nevo.co.il/law_html/law01/125_ 020.htm

Nevo. (2013). Defining residential plans and a small apartment, Article 147(b), Israel planning and building regulations, 2013. Nevo. Retrieved from https:// www.nevo.co.il/law_html/law19/500_844.htm

Population and Immigration Authority. (2018). Foreign workers' rights handbook. Jerusalem: Population and Immigration Authority. Retrieved from https://mfa.gov.il/MFA/ConsularServices/ Documents/ForeignWorkers2018.pdf

Rabinowitz, M. (2017). Mabat el uchlusiat hazkenio betahalichei hithadshurt ironit [A look at the population of the elderly in urban renewal]. Tel Aviv: Hagar, The Affordable Housing Center and Tel Aviv University. Retrieved from http://din-online.info/pdf/hg7.pdf

Rawls, J. (1971). A theory of justice. Oxford: Oxford University Press.

Refworld. (1991). Foreign Workers Law 5751-1991, Israel Employment Law, 1 May 1991. Retrieved from https://www.refworld.org/docid/4c36ed992.html

Regev, M. (2001). Mavo latarbut haisraelit [Introduction to Israeli culture]. In E. Yaar \& Z. Shavit (Eds.), Megamot bahevra hisraelit [Trends in Israeli society] (pp. 823-898). Tel Aviv: The Open University.

Shadar, H., \& Yacobi, H. (2014). Mechonat hamegurim likrat moderniut alternativit [The residential machine: Towards alternative modernism]. Israeli Sociology, 16(1), 54-81.

Skolnick, A. S., \& Skolnick, J. H. (2007). Family in transition. London: Pearson Education.

Thompson, D. (Ed.). (1998). The Oxford dictionary of current English. Oxford: Oxford University Press.

Tidhar, D. (1956). Professor Alexander Klein. In D. Tidhar (Ed.), Encyclopaedia of the founders and builders of Israel (Vol. 7, p. 2812). Retrieved from http://www. tidhar.tourolib.org/tidhar/view/7/2812

Turiel, E. (1996). Equality and hierarchy: Conflict in values. In E. S. Reed, E. Turiel, \& T. Brown (Eds.), The Jean Piaget symposium series. Values and knowledge (pp. 75-101). Mahwah, NJ: Lawrence Erlbaum Associates.

Vollmer, J. L., Schulze, P. A., \& Chebra, J. M. (2005). The American master bedroom: Its changing location and significance to the family. Journal of Interior Design, 31(1), 1-13.

Wenger, T., \& Naor, C. (2019). Kli avoda arzi lekviat tamhil duir razuy [National tool to determine a desirable housing mix] [PowerPoint presentation]. Israel Planning Administration. Retrieved from https://www.gov.il/BlobFolder/guide/subject_ quality_planning/he/District_planning_institutions_ IPLAN_for_who_whe_are_planning-tal_wenger.pdf

Wiedenhoeft, R. V. (1985). Berlin's housing revolution: German reform in the 1920s. Ann Arbor, MI: UMI Research Press.

World Health Organization. (2018). Global Health observatory, life expectancy and healthy life expectancy. World Health Organization. Retrieved from https://www.who.int/data/gho/data/themes/ topics/indicator-groups/indicator-group-details/ GHO/life-expectancy-and-healthy-life-expectancy

\section{About the Authors}

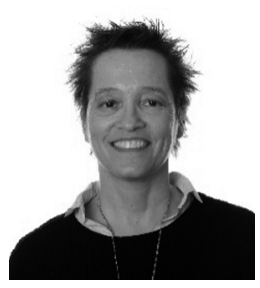

Shelly Cohen (PhD) is a Researcher, Curator and Architect. Her PhD dissertation (Tel Aviv University), explores the relationships between the ethical, social and aesthetic aspects of the activism of architects who join initiatives to plan and build projects for Israel's marginalized groups. Her post-doctoral research (Technion IIT) explores the shared residential architecture of seniors living with caretakers. She curated a series of exhibitions entitled 'Local,' at the Architect's House Gallery in Jaffa, which examined political aspects of Israeli space.

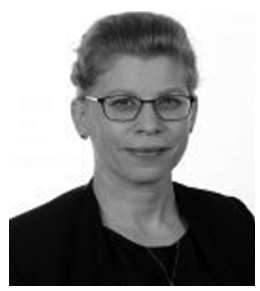

Yael Allweil (PhD) is an Architect and Assistant Professor in the Faculty of Architecture and Town Planning at the Technion, Israel, where she heads 'HousingLab: History and Future of Living.' She completed her PhD in architecture history at UC Berkeley exploring the history of Israel-Palestine as a history of the gain and loss of citizen housing. Her research was published in the monograph Homeland: Zionism as Housing Regime 1860-2011 (Routledge, 2017) and in journal articles from the journals Urban Studies, Footprint, ACME, City, and others. 